\title{
Theory Construction and Practice of Choosing a Historic City as a Travel Destination Using Visual Narrative Art
}

\author{
Lin Hui-Wen
}

\begin{abstract}
Multiple forces-the evolution of the environment, changes to the cityscape, economic development, and the surge of tourists - have acted on Tainan to compel the city in southern Taiwan to face gradual changes in the roles of its rich cultural and historical resources. As images of the historic city have inundated diverse forms of media, the identity of the city has naturally undergone dynamic changes and adjustments. Regardless of whether tourists or bloggers visit Tainan of their own volition or as the result of marketing policies implemented by the government, what defines a "historic city" in the minds of tourists and residents? Is it the broad and general imagery of the local food, historic sites, traditional alleys and lanes, or ceremonies? Or is it defined by an intangible way of life, such as the unexposed or undiscovered latent imagery of historical legends and myths? These questions are at the heart of this study We attempted to answer these questions by examining the innermost feelings and perceptions of consumers (i.e., tourists) visiting Tainan. However, prior to the study, the visitors were aware of their understandings of the historic city hidden in their subconscious. Therefore, we used visual narrative art (VNA) to delve into and identify the imagery that tourists associate with their destination. VNA can be used to investigate the subconscious or unconscious internal perceptions and behaviours of the tourists (i.e., the consumers). The oldest storytelling tool, VNA acts as a key to a more profound understanding of how tourists behave and how to increase tourism.
\end{abstract}

Index Terms-City, Identity, Tourists, Travel destination, Visual narrative art.

\section{INTRODUCTION}

Tainan is a historic city that was once the military, political, and economic centre of Taiwan during the Dutch rule. It has also endured rule by the Ming Dynasty, the Qing Dynasty, and Japan. Because its history spans multiple centuries, Tainan has the most impressive and richest cultural assets and historical resources. Tainan claims 22 national historic sites, the most of any cities in Taiwan, which has an area of only 36,000 square kilometres, as well as 7 Level One Historic Sites. A wide range of traditional religious ceremonies is still performed in Tainan and is the most distinctive element of Tainan's intangible cultural heritage. Once known as Taiwan's Capital City, Tainan was built in 1725 . The city marked its 293rd anniversary in 2018, and has begun the countdown to its 300 th anniversary. Tainan provides tourists

Manuscript received December 30, 2017; revised May 1, 2018. This work was supported in part by the Ministry of Science and Technology under Grant 105-2410-H-006 -065.

Lin Hui-Wen is with the Institute of Creative Industries Design, National Cheng Kung University, Tainan, Taiwan (e-mail: hwlin@ mail.ncku.edu.tw). with the gourmet brands, massive amounts of cultural assets, and rich and multilayered history of the Capital City. In recent years, these benefits have become focal points in the government's active marketing promotions. In both printed tourism publications and Internet travel guides, the focus has been on historical sites, cultural assets, and food. What effect do these visual images have and what role do they play in the latent imagery of Tainan, in shaping the imagery of Tainan as a historic city, and in Tainan's identity? The imagery associated with a historic city that is elicited by the impact of the visitors' own emotions or perceptions about touring a historic city and the visitors' subconscious perceptions and feelings regarding Tainan are as yet unexplored and are the topics examined in this study. Imagery refers both to stimuli depicted in the real world and to those more elusive and unique representations perceived only in the mind's eye [1]. In recent years, the government has surveyed, ranked, restored, and reused cultural assets at all levels to pursue innovative business models that can attract new business opportunities. Tainan has actively promoted cultural and creative industry policies, but as a historic city, it must protect the cultural values at its core and carefully consider how do to so through innovations and activation of the fine adjustments between history or culture and economic benefits. First and foremost, Tainan must revisit the discovery and identification of rich cultural imagery associated with being a historic city. A particularly urgent mission as Tainan begins the countdown to its 300th anniversary is how to transmit the core values through marketing and effectively join innovation with creativity. Discovering and exploring the latent imagery that leads to the choice of Tainan as a historic city destination were the motivations for this study. Therefore, the first steps of this study were to divide the visual narrative theories, practices, and research related to the choice of a historic city as a travel destination in one of four categories: (a) Decode the visual narrative art (VNA) of tourists regarding the branding of a historic city destination; (b) apply the Zaltman metaphor elicitation technique (ZMET) to the analysis of tourists' travel-related behaviours and perceptions; (c) use the storytelling of tourists to construct their travel experiences; and (d) capture the tourists' interpretation of the place, people, and events during their visit to the Capital City. Based on these categories, it is analysed and encoded the visual imagery contained in the official tourism website and print material supplied by the Tainan City government. The author used ZMET, a visual image analysis method, to examine common beliefs held by tourists about the symbolism of a historic city destination. The author also used netnography to decode imagery about the tourists' destination. Faced with the massive influx of tourists to this marketable historic city, 
Tainan's top priority shall be placed on deliberating how to simultaneously satisfy tourist expectations and provide a clear definition of its core values. This is a burden that must be shouldered by Tainan in its role as a historic city. The diverse policies to market and promote Tainan have generated tourism from all market sectors. Tourists arrive simultaneously from different times, different places, and with different intentions to engage in all different types of consumption (including cultural, entertainment, and functional consumption). Tainan, which seeks to be a historic city, must emulate other historic cities worldwide and operate as a branded destination. However, Tainan must adhere to the principle of protecting its core values and spirit as it attempts to satisfy the demands of its target consumers. Is the image of Tainan that is actively marketed by the government similar to the perceptions held by visitors to this historic city, or are there other facets that are deeper and more representative of Tainan? Only by a more profound understanding of the as yet undiscovered essence of Tainan and of the insights of tourists who view Tainan as a historic city will we have the opportunity to activate this imagery as people begin to plan for the 300th anniversary of Tainan. This understanding will allow deeper and more thorough discourse about the marketing of this historic city and provide guidelines for implementing new marketing policies.

\section{Methodology: The USE OF THE VISUAL EXPLORATION METHOD}

In the 1960s, Collier proposed that images and photographs could be used to elicit undiscovered questions in anthropology. He believed that the visual images produced by cameras could be used to decode meaning hidden in the subconscious and could be used to explore the experiences of particular individuals in the field (e.g., a site or a place) [2]. Professor Zaltman, who first developed ZMET, uncovered the motivations, thoughts, and beliefs hidden in consumer thoughts in How Customers Think: Essential Insights into Mind of the Market [3]. He explored the complete metaphorical journey from the familiar to the innovative through the narrative process. Based on his work, we analysed the internal perceptions of consumers from the perspective of visual anthropology. Using VNA as the primary research method, the author delved deeply into the subconscious beliefs and perceptions that tourists hold about historic cities. VNA is the most ancient medium for narrative. It is also the key to an increased understanding of tourism behaviour at a deeper level. VNA involves using one or two images that can be applied to or that exist within a story. These images, which can be pictures, photographs, physical actions, movies, or other media, are used to describe the setting and/or the activities and events in the story. VNA can elicit meaning beyond what can be accomplished through verbal reporting. It can transmit internal thoughts and ideas regarding symbols, people, and other objects. VNA is also the oldest medium for storytelling. Through both language and textual processing, VNA can also help interviewer access information that cannot be accessed through oral interviews alone [4].

The present study was conducted in four stages. In the first stage, official information regarding the historic city in print publications and virtual web pages was collected and organized. Cluster analysis was performed to categorize the images and to define dimensions of the visual content's themes and symbols. In the second stage, participants were recruited. The author performed hierarchical sampling on visitors to the Capital City and selected six representative participants. These participants used disposable cameras provided by us to capture ten photographs of their visit to the Capital City. These ten photographs were used in in-depth interviews that were based on ZMET. Photographs are one of the most effective reminders of people's vacation and are considered the latest product of travel experiences [5]. The author explored the participants' introspectives and constructed mind models to analyse their innermost feelings regarding historic cities.

Finally, a consensus map was created. In the third stage, the author applied netnography research methods, which are used in visual anthropology, to the Internet travel logs of bloggers after their visits to the Capital City. These bloggers told the stories of their visits using both verbal and nonverbal data. ZMET was used a second time to analyse representative positive and negative reports of Tainan as a destination to construct mind models and consensus maps. In the fourth and final stage, the author performed cross comparisons to organize and present thorough data about the perceptions of visitors both during and after their travels. Using this data, it is identified the internal emotional connections, internal needs, and tourism behaviours regarding a historic city. (Table 1.) Using storytelling, sensory images, missing images, most representative images, and opposite images [3]. A consensus map was created that integrated information from the previous stages. In addition, the author decoded tourist archetypes with unique characteristics, which can be provided to the government or private organizations for the future creation of marketing guidelines and strategies that emphasize the imagery and symbolism of Tainan. (Fig. 1)

TABLE I: ANALYTICAL OF CATEGORIES THROUGH ROSS COMPARISON ON BLOGGERS AND INSTAGRAM

\begin{tabular}{|l|l|l|}
\hline Classifications & $\mathrm{B}$ logger & Instagram \\
\hline Gastronomy & $\mathrm{N}=71 / 54 \%$ & $\mathrm{~N}=29 / 21 \%$ \\
\hline Accommodation & $\mathrm{N}=18 / 14 \%$ & $\mathrm{~N}=3 / 2 \%$ \\
\hline Interactive experience & $\mathrm{N}=16 / 12 \%$ & \\
\hline Photo spots & $\mathrm{N}=9 / 7 \%$ & $\mathrm{~N}=59 / 42 \%$ \\
\hline Leisurely slow pace & $\mathrm{N}=9 / 7 \%$ & $\mathrm{~N}=41 / 29 \%$ \\
\hline
\end{tabular}

\section{UNCOVERING AND ANALYSING TOURIST BEHAVIOURS AND INTERNAL PERCEPTIONS}

The VNA research method included the use of ZMET, which was a key tool in this methodology. This allowed the author to create a visual image framework of the tourists' travel objectives. The first step in this process was to collect and categorize official images. The author began with official pamphlets, brochure and the website provided by Tainan City Government's Tourism Bureau. The author categorized all data by six major dimensions: historical sites, memorial sites, holidays and festivals, religious temples, natural landmarks, and consumer spending. These six major dimensions 
represented different facets emphasized by the official tourism. After this categorization, image captions, themes, and perspectives were analysed, to identify subcategories of intended information transmission to better understand the information transmitted by the images in these categories and the subcategories that were used to transmit information to the public. The information transmitted in each category and their relative weights are shown in the following table. (see Table II).

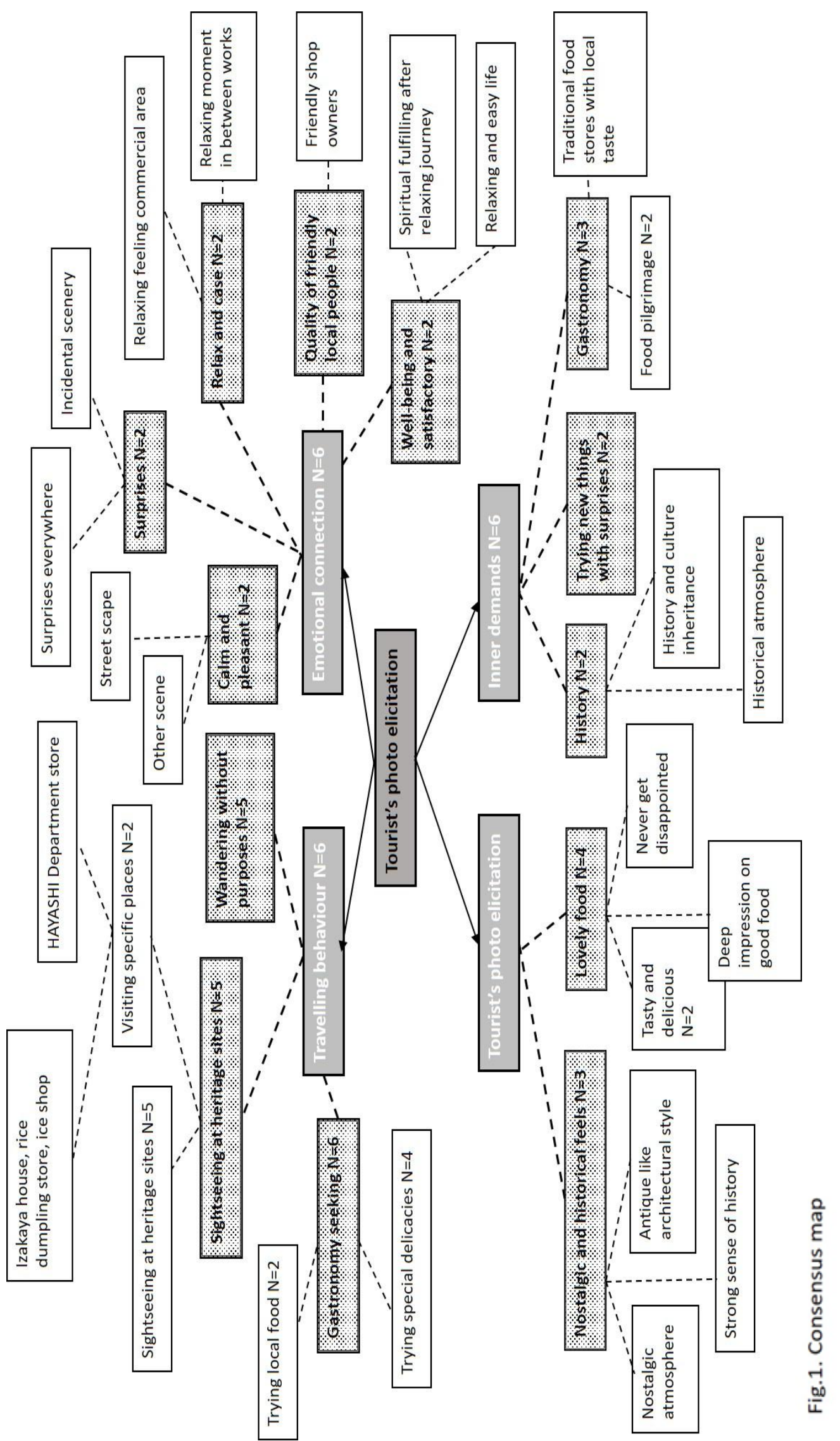

Fig. 1. Consensus map. 
TABLE II: ANALYSEd Result From Print PUblications AND Web PAGES

\begin{tabular}{|c|c|c|c|}
\hline $\begin{array}{l}\text { Six } \\
\text { dimensions } \\
\text { /number of } \\
\text { frequency }\end{array}$ & $\begin{array}{l}\text { Most frequent } \\
\text { mentioned } \\
\text { category }\end{array}$ & $\begin{array}{l}\text { Second most } \\
\text { mentioned } \\
\text { category }\end{array}$ & $\begin{array}{l}\text { Third most } \\
\text { mentioned } \\
\text { category }\end{array}$ \\
\hline $\begin{array}{l}\text { Heritage and } \\
\text { historic sites } \\
/ \mathrm{n}=101\end{array}$ & $\begin{array}{l}\text { Heritage as } \\
\text { attractions } \\
(\mathrm{n}=30 / 29 \%)\end{array}$ & $\begin{array}{l}\text { Architectural } \\
\text { characters } \\
(n=19 / 19 \%)\end{array}$ & $\begin{array}{l}\text { Aura of art and } \\
\text { culture } \\
(n=13 / 13 \%)\end{array}$ \\
\hline $\begin{array}{l}\text { Memorial } \\
\text { sites } \\
/ \mathrm{n}=67\end{array}$ & $\begin{array}{l}\text { Exhibition } \\
\text { theme } \\
(n-19 / 28 \%)\end{array}$ & $\begin{array}{l}\text { Displayed } \\
\text { exhibits } \\
(n=17 / 25 \%)\end{array}$ & $\begin{array}{l}\text { Biographical } \\
\text { info of } \\
\text { historical sites } \\
(\mathrm{n}=17 / 25 \%)\end{array}$ \\
\hline $\begin{array}{r}\text { Festivals and } \\
\text { events } / \mathrm{n}=7\end{array}$ & $\begin{array}{l}\text { Traditional } \\
\text { crafts } \\
\quad(n=6 / 86 \%)\end{array}$ & \multicolumn{2}{|c|}{ Folklore tradition $(n=1 / 14 \%)$} \\
\hline $\begin{array}{l}\text { Religions and } \\
\text { temples } \\
/ \mathrm{n}=61\end{array}$ & $\begin{array}{l}\text { Religious } \\
\text { background } \\
(\mathrm{n}=49 / 30 \%) \\
\end{array}$ & $\begin{array}{l}\text { Traditional } \\
\text { custom } \\
(n=37 / 23 \%)\end{array}$ & $\begin{array}{l}\text { Special names } \\
(\mathrm{n}=30 / 19 \%)\end{array}$ \\
\hline $\begin{array}{l}\text { Natural } \\
\text { landscape } \\
/ \mathrm{n}=91\end{array}$ & $\begin{array}{l}\text { Natural } \\
\text { landscape scene } \\
n=(34 / 37 \%)\end{array}$ & $\begin{array}{l}\text { Leisure facilities } \\
(n=24 / 26 \%)\end{array}$ & $\begin{array}{l}\text { Ecological } \\
\text { environment } \\
(n=17 / 19 \%) \\
\end{array}$ \\
\hline $\begin{array}{l}\text { Consumer } \\
\text { spending } \\
/ \mathrm{n}=509\end{array}$ & $\begin{array}{l}\text { Gastronomy } \\
(n=220 / 43 \%)\end{array}$ & $\begin{array}{l}\text { Consuming } \\
\text { places } \\
(\mathrm{n}=188 / 37 \%) \\
\end{array}$ & $\begin{array}{l}\text { Consuming } \\
\text { products } \\
(\mathrm{n}=59 / 12 \%)\end{array}$ \\
\hline
\end{tabular}

The analysis of official promotional material showed that images in the consumer spending dimension were most common, followed by images in the religious temple dimension. Gastronomy was the primary theme of material in the consumer spending dimension. However, the majority of these pictures were independent images unaccompanied by captions. They served merely as enhancements or decorations in the pamphlets or web pages. Although the amount of material in the consumer spending dimension greatly outnumbered material in all other dimensions, the amount of information transmitted by these images was limited. In contrast, material in the religious temple and historical site dimensions all comprised images paired with words that expressed the historical significance or uniqueness of the landmark; thus, this material transmitted thorough information regarding the landmark to the reader (i.e., the tourist). Regardless of dimension, the captions introduced the images through unidirectional, descriptive language. Images of activities involving tourists or locals were almost never found.

The second stage involved using ZMET to uncover data and to organize and analyse tourism behaviours and perceptions. This stage was divided into six processes: searching for images, using images in interviews, organizing and comparing images, metaphors in the images, sensory images, and links and analyses. (Fig. 2)

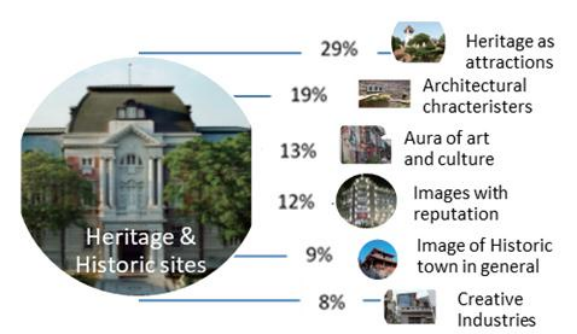

Fig. 2. The most mentioned dimension of Heritage \& Historic sites with its' categories.

\section{NETNOGRAPHY TO ANALYSE BLOGGERS' POST-TRIP STORYTELLING}

For a more comprehensive understanding of the reasons why tourists choose Tainan as a destination and the internal needs of their tourism behaviours, the author used netnography as one of the research methods. In visual rhetoric, scholars have transposed reading practice onto images in order to decipher how images communicate and construct certain identifications and ways of seeing [6]. Increasing number of studies undertake netnography on tourist experiences found that these data are unbiased and unprompted responses from travellers [7] [8].

Author collected blog posts that discussed travelling to Tainan and were posted within the last two years. The author analysed the correlation between the images and the words as well as the intended message. Tourism experiences which are perceived to be self-relevant or self-beneficial to individual travellers were also reported by bloggers as memorable experiences [9]. Post from Instagram, a social media mobile application that primarily focuses on photographs, was also collected, based on ZMET. Using a keyword search, the author extracted data related to Tainan tourism. Analysed information contained in the images and text as well as the message behind the content. Finally, it is identified two types of results from the data: (1) the experiences and feelings of tourists who chose Tainan as their destination and (2) the tourists' behaviours and internal needs.

1) Reasons why tourists chose travel to Tainan: The analysis of blog and Instagram posts for why tourists chose Tainan as their destination showed that among blog posts, the most common topic was food, followed by lodgings or accommodations. In contrast, among Instagram posts, the most common topic was scenery, followed by food. It is analysed the underlying reasons for these results and determined that they were related to the nature of blog and Instagram posts. The primary purpose of blog posts was advertisement or promotion. Some bloggers were chosen by businesses to write sponsored posts. Therefore, the majority of blog posts emphasized consumption. In contrast, Instagram is a social media app that emphasizes photographs. Young generations that used Instagram primarily wanted to share photographs of scenery. Further examination of Instagram posts showed that a secondary reason for visiting Tainan was the casualness of Tainan. This indicated that an increasing number of people chose Tainan as their destination because they wanted to travel light or because they wanted a relaxed, unstructured trip; therefore, "casual" travel was more prevalent.

2) Behaviours and internal needs of tourists to Tainan: In this stage of analysis, we analysed blog and Instagram posts. Results were similar to those from travel purposes. The most common topic of blog posts was featured foods in the major category culinary capital; the most common topic of Instagram posts was man-made attractions in the major category of culture and scenery. This was consistent with the previously described nature of blogs and Instagram. It also indicated that these two major categories represented the behaviours and internal 
needs of the majority of tourists to Tainan.

\section{FINDINGS}

After consolidating the data collected from the in-depth interviews and the data gathered from the Internet, it is found that tourists visited Tainan primarily to take a casual unstructured trip, to taste featured foods, and to take photographs. They perceive Tainan as having a leisurely and slower pace of life; this perception was built on the local style and personality of the city. To tourists, Tainan is a place filled with human kindness. Its cityscape evokes times past and the city has many unique characteristics. The majority of visitors tended to experience this city at a more leisurely pace. They took the opportunity to achieve emotional connections at each landmark they visited to gain a sense of physical and spiritual relaxation.

TABLE III: ANAYTICAL SENSORY FINDING OF PARTICIPANTS

\begin{tabular}{|c|c|c|c|c|c|c|c|c|c|c|}
\hline \multirow{2}{*}{ Participant } & \multicolumn{2}{|c|}{$\begin{array}{l}\text { Colour (match+ } \\
\text { /incompatible-) }\end{array}$} & \multicolumn{2}{|c|}{$\begin{array}{l}\text { Sound (match+ } \\
\text { /incompatible-) }\end{array}$} & \multicolumn{2}{|c|}{$\begin{array}{l}\text { Smell (match+ } \\
\text { /incompatible-) }\end{array}$} & \multicolumn{2}{|c|}{$\begin{array}{l}\text { Touch (match+ } \\
\text { /incompatible-) }\end{array}$} & \multicolumn{2}{|c|}{$\begin{array}{l}\text { Taste (match+ } \\
\text { /incompatible-) }\end{array}$} \\
\hline & + & - & + & - & + & - & + & - & + & - \\
\hline $\begin{array}{c}1 \\
\text { (Female) } \\
\text { 42yrs }\end{array}$ & $\begin{array}{l}\text { misty } \\
\text { blue, } \\
\text { navy, } \\
\text { vintage } \\
\text { colour }\end{array}$ & $\begin{array}{l}\text { sharp } \\
\text { blue }\end{array}$ & $\begin{array}{l}\text { Vendor } \\
\text { selling } \\
\text { sound, } \\
\text { laughin } \\
\text { g }\end{array}$ & $\begin{array}{l}\text { quiet, } \\
\text { hushed }\end{array}$ & $\begin{array}{l}\text { Aroma } \\
\text { of food }\end{array}$ & $\begin{array}{c}\text { Air } \\
\text { pollutio } \\
n\end{array}$ & $\begin{array}{l}\text { Warm } \\
\text { hugs }\end{array}$ & $\begin{array}{l}\text { Cold, } \\
\text { low } \\
\text { temper } \\
\text { ature }\end{array}$ & $\begin{array}{l}\text { Nostalg } \\
\text { ic taste } \\
\text { gone } \\
\text { with } \\
\text { time }\end{array}$ & $\begin{array}{l}\text { Light } \\
\text { and } \\
\text { plain }\end{array}$ \\
\hline $\begin{array}{c}2 \\
\text { (Female) } \\
\text { 20yrs }\end{array}$ & $\begin{array}{l}\text { light } \\
\text { blue }\end{array}$ & $\begin{array}{c}\text { Black, } \\
\text { dark } \\
\text { shade }\end{array}$ & $\begin{array}{c}\text { crosstal } \\
\text { k, } \\
\text { folklore } \\
\text { like, pop } \\
\text { music }\end{array}$ & $\begin{array}{l}\text { classic } \\
\text { al } \\
\text { music, }\end{array}$ & $\begin{array}{c}\text { aroma } \\
\text { of } \\
\text { coffee, } \\
\text { closer } \\
\text { gets } \\
\text { stronge } \\
r\end{array}$ & $\begin{array}{c}\text { Perfum } \\
\text { e, } \\
\text { delicate } \\
\text { smell }\end{array}$ & $\begin{array}{c}\text { Grassla } \\
\text { nd, soft } \\
\text { soil, } \\
\text { fluffy }\end{array}$ & $\begin{array}{l}\text { Rough } \\
\text { texture, } \\
\text { asphalt } \\
\text { road }\end{array}$ & $\begin{array}{l}\text { Stinky } \\
\text { tofu in a } \\
\text { good } \\
\text { sense, }\end{array}$ & $\begin{array}{l}\text { empty } \\
\text { heart } \\
\text { like } \\
\text { marsh } \\
\text { mallow }\end{array}$ \\
\hline $\begin{array}{c}3 \\
\text { (Male) } \\
25 y r s\end{array}$ & $\begin{array}{c}\text { transluc } \\
\text { ent }\end{array}$ & green & $\begin{array}{l}\text { reverber } \\
\text { ating } \\
\text { sound } \\
\text { blended } \\
\text { with sea } \\
\text { waves } \\
\text { and } \\
\text { chantin } \\
\text { g sound }\end{array}$ & $\begin{array}{l}\text { rhythm } \\
\text { ed }\end{array}$ & $\begin{array}{l}\text { burning } \\
\text { incense }\end{array}$ & $\begin{array}{l}\text { sea, } \\
\text { fishy } \\
\text { and } \\
\text { salty } \\
\text { smell }\end{array}$ & $\begin{array}{l}\text { sea } \\
\text { shell } \\
\text { mix } \\
\text { with } \\
\text { sand }\end{array}$ & $\begin{array}{c}\text { jelly } \\
\text { puddin } \\
\text { g, } \\
\text { smooth }\end{array}$ & $\begin{array}{c}\text { water } \\
\text { with a } \\
\text { pinch of } \\
\text { salt }\end{array}$ & sugar \\
\hline $\begin{array}{c}4 \\
\text { (Female) } \\
\text { 26yrs }\end{array}$ & $\begin{array}{l}\text { Red } \\
\text { blend } \\
\text { with } \\
\text { black }\end{array}$ & silver & $\begin{array}{l}\text { children' } \\
\text { crispy } \\
\text { laughin } \\
\text { g sound } \\
\text { like bell }\end{array}$ & $\begin{array}{l}\text { Insect } \\
\text { sounds }\end{array}$ & $\begin{array}{l}\text { sandal } \\
\text { wood, } \\
\text { ink }\end{array}$ & $\begin{array}{l}\text { exhaust } \\
\text { pipe }\end{array}$ & $\begin{array}{l}\text { rough } \\
\text { texture } \\
\text { of } \\
\text { bricks }\end{array}$ & $\begin{array}{l}\text { loved } \\
\text { one's } \\
\text { hand }\end{array}$ & $\begin{array}{c}\text { sweet } \\
\text { but } \\
\text { salty }\end{array}$ & $\begin{array}{l}\text { no } \\
\text { respon } \\
\text { se }\end{array}$ \\
\hline $\begin{array}{c}5 \\
\text { (Female) } \\
22 y r s\end{array}$ & ink & $\begin{array}{l}\text { coin's } \\
\text { colour }\end{array}$ & bird sing & $\begin{array}{l}\text { Insect } \\
\text { sounds }\end{array}$ & $\begin{array}{l}\text { aroma } \\
\text { of tea }\end{array}$ & $\begin{array}{c}\text { cigarett } \\
\mathrm{e}\end{array}$ & stove & sand & $\begin{array}{l}\text { light } \\
\text { sweet } \\
\text { brown } \\
\text { sugar }\end{array}$ & bitter \\
\hline $\begin{array}{c}6 \\
\text { (Female) } \\
\text { 35yrs }\end{array}$ & brown & $\begin{array}{l}\text { metallic } \\
\text { colour } \\
\text { like } \\
\text { gold, } \\
\text { silver or } \\
\text { bronze }\end{array}$ & $\begin{array}{c}\text { relax } \\
\text { and } \\
\text { soothin } \\
g \text { music }\end{array}$ & $\begin{array}{c}\text { heavy } \\
\text { metal } \\
\text { rock } \\
\text { music }\end{array}$ & $\begin{array}{c}\text { old } \\
\text { books, } \\
\text { historic } \\
\text { al } \\
\text { architec } \\
\text { ture }\end{array}$ & $\begin{array}{l}\text { spicy } \\
\text { pot }\end{array}$ & wood & $\begin{array}{l}\text { cold } \\
\text { metal }\end{array}$ & $\begin{array}{c}\text { homelik } \\
\text { e }\end{array}$ & $\begin{array}{c}\text { urban } \\
\text { polluted } \\
\text { smell }\end{array}$ \\
\hline
\end{tabular}

From the words that visitors used to describe their perceptions about Tainan, it is found that certain internal perceptions, such as local human kindness, religious beliefs, landmarks with rich context and cultural heritage, were the most touching and created the deepest impressions after their visits. Our analysis of blog and Instagram posts corroborated that "casual" was the primary travel attitude. After comparing the official promotional messages with the behaviours, purposes, feelings, and perceptions of tourists to Tainan (Table 3.), it is found that the majority of the official information comprised food in the consumer spending category. However, most of this information served as decorations in the pamphlets or web pages. Because the images were not accompanied by text, the amount of information transmitted by these images was limited. In addition, it is found that official information primarily emphasized historic sites and religious temples or even memorial sites or physical landmarks related to history or culture. The purpose of the transmitted information was the introduction of the background, history, or origin of these places. The information was relatively descriptive and conventional. However, this ignores the fact that one of the tourist's internal needs is the wish to form more connections with the local human kindness and to achieve spiritual satisfaction and relaxation from their travels. Although tourists were provided with a great deal of information 
regarding historical or religious sites, this information rarely resonated with the tourists as a reason for choosing Tainan as their destination.

\section{CONCLUSION}

In recent years, Taiwan government has prioritised and worked on the investigation, legislation, conservation, rehabilitation, and reuse cultural heritage according to various status. Innovative managements and marketing strategies have been launched to generate economic impact. The historic city of Tainan has faced the challenge of branding its image without losing the reputation of cultural and historical dimensions as well as maintaining the core value of culture.

This research has implemented the ZMET technique on eliciting tourist' travel experience also demonstrate the perceptions toward the inherited historic city. Through the application of storytelling narrated by tourists, it is discovered that there are gaps between the image delivered and the image received, the former from authority and latter of intimate encounters with the city by travellers. This research has contributed the rethinking of the relationship between what is provided and what is demanded from the consumption perspective. The applied VNA approach has not only provided provocative approach towards understanding experiences, perceptions and feelings tourists have, but also revealed the reflexive perspective of image providers and receivers among government and visitors through collecting textual, visual as well as digital data to gain comprehensive insights of the travel destination image. Future research can be expanded to absorb larger number of samples to decipher wider range of demographic population.

\section{REFERENCES}

[1] M. Kozak and A. G. Woodside, Tourists' Behaviors and Evaluations, Bingley, U.K: Emerald, 2014.

[2] M. D. Olien, Review of Visual Anthropology: Photography as a Research Method, Wiley on behalf of the American Anthropological Association, 1968.

[3] G. Zaltman, "Rethinking market research: Putting people back in," Journal of Marketing Research, vol. 34, no.4, pp. 424-437, 1997.
[4] A. Woodside and C.M., Megehee, "Travel Storytelling Theory and Practice," Anatolia: An International Journal of Tourism and Hospitality Research, vol. 20, no.1, pp. 86-99, 2012.

[5] R, Ekici and B. Cizel, "Analysis of tourism experiences through photographs according to tourist gaze typologies," in Proc. the Multidisciplinary Academic Conference. Pp. 777-790, Aug, 2017.

[6] L. E. Gries, "Iconographic tracking: A digital research method for visual rhetoric and circulation studies," Computers and Composition, vol. 30, no. 4, pp. 332-348, 2013.

[7] R. V., Kozinets, "On netnography: Initial reflections on consumer research investigations of cyber-culture," Advances in Consumer Research, vol. 25, no. 1, pp. 366-371, 1998.

[8] D. Martin, and A. G. Woodside, "Storytelling research on international visitors: Interpreting own experiences in Tokyo," Qualitative Market Research: An International Journal, vol. 14, no. 1, pp. 27-54. 2011.

[9] L, Chandralal, J. Rindfleish, and F. Valenzuela, "An application of travel blog narratives to explore memorable tourism experiences," Asia Pacific Journal of Tourism Research, vol. 20, no. 6, pp. 680-693, 2015.

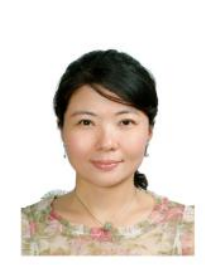

Hui-Wen Lin is an associate professor at the Institute of Creative Industries design in National Cheng Kung University in Taiwan. She is also the Associate Librarian in the university library. She earned her Ph.D. in Architecture (2008) at National Cheng Kung University in Taiwan, her M.A. (1999) and B.A. (hons) (1997), both in interior design, from Manchester Metropolitan University in the UK.

She joined the National Cheng Kung University faculty in 2012. Prior to that she was a faculty member at the Kun Shan University of Technology at the Department of Spatial Design (1999-2012). She was awarded the Best Teaching in 2011. She was invited to be the Visiting Scholar at the Centre of Humanity and Social Science in the National Science Council in Taiwan (July, 2013) as well as the Visiting Scholar in Fudan University in China (April, 2013). Her recent achievement is to be awarded as the Distinguished Teaching Faculty in 2016. Her experiences and expertise has enabled her to contribute over 30 research papers to conferences and Journals. These have mainly focused on issues relating to the sites and places that are associated with significant events, for their social and cultural meanings. Her research outcomes include the paper published in the International Journal of Heritage Studies was also published by Taylor \& Francis in 2015, under title of "The selected representation of contested prison history: memorial exhibitions and tourist experiences.

Dr. Lin has been a member of the International Council on Monuments and Sites (ICOMOS) since 2013. She has also been elected as Board member of the Foundation of Historic City Conservation and Regeneration in 2012. 